Tropical Journal of Pharmaceutical Research April 2016; 15 (4): 695-699

ISSN: $1596-5996$ (print); 1596-9827 (electronic)

(C) Pharmacotherapy Group, Faculty of Pharmacy, University of Benin, Benin City, 300001 Nigeria.

All rights reserved.

Available online at http://www.tjpr.org

Original Research Article

http://dx.doi.org/10.4314/tjpr.v15i4.4

\title{
Effect of recombinant human erythropoietin expressions of apoptosis genes in rats following traumatic brain injury
}

\author{
Xuesong Yuan ${ }^{1 \star}$, Xiaoxing Bian ${ }^{1}$, Wenfeng Wei ${ }^{1}$, Yin Tang ${ }^{2}$ and Qing Bao ${ }^{1}$ \\ ${ }^{1}$ Department of Neurosurgery, ${ }^{2}$ Department of Pathology, The Affiliated Wujin Hospital of Jiangsu University, Changzhou \\ Jiangsu, 213002, PR China \\ *For correspondence: Email: yuan_cedar@sina.com; Tel: +8613775093132
}

Received: 1 October 2015

Revised accepted: 7 March 2016

\begin{abstract}
Purpose: To explore the effect of recombinant human erythropoietin (r-HuEPO) on apoptosis in rats after traumatic brain injury.

Methods: A total of 48 traumatic brain-injured Sprague Dawley (SD) rats were obtained by improved Feeney's traumatic brain injury model, and were randomly divided into four groups: normal salinetreated rats (control) and rats treated with r-HuEPO at doses of $1000 \mathrm{U} / \mathrm{kg}, 3000 \mathrm{U} / \mathrm{kg}$ and $5000 \mathrm{U} / \mathrm{kg}$. Brain tissues were collected on the 7th day after trauma surgery. Apoptotic cells, and NF-kappa B (NF$\kappa B)-, c-m y c-$, and Fas/Fasl-positive cells were identified in brain tissues by immunohistochemical assay. Results: After treatment with r-HuEPO (3000 and $5000 \mathrm{U} / \mathrm{kg}$ ), expression of NF-KB and Fas/Fas/ were significantly decreased $(p<0.05)$ compared to control rats, especially at the $5000 \mathrm{U} / \mathrm{kg}$ dose $(p<0.01)$. However, for c-myc, no significant difference was observed between $r$-HuEPO treatment and control groups $(p>0.05)$. Compared to the $1000 \mathrm{U} / \mathrm{kg} r$-HuEPO group, Fas/Fasl expression levels were significantly lower in the 3000 and $5000 \mathrm{U} / \mathrm{kg} r$-HuEPO groups $(p<0.05)$. Additionally, expression of $N F-K B$ and Fasl in the $5000 \mathrm{U} / \mathrm{kg} \mathrm{r}$-HuEPO group was significantly lower than that in the $3000 \mathrm{U} / \mathrm{kg} \mathrm{r}$ HuEPO group $(p<0.05)$. Moreover, the number of apoptotic cells in the r-HuEPO group (5000 U/kg) was significantly lower than in the control group $(p<0.05)$.

Conclusion: Thus, r-HuEPO may be beneficial for treating traumatic brain injury via inhibition of NFkappa $B$ and Fas/Fas/ expressions.
\end{abstract}

Keywords: Recombinant human erythropoietin, NF-kappa B, Traumatic brain injury, Apoptosis, Neuronal damage, Fas/Fasl expression

Tropical Journal of Pharmaceutical Research is indexed by Science Citation Index (SciSearch), Scopus, International Pharmaceutical Abstract, Chemical Abstracts, Embase, Index Copernicus, EBSCO, African Index Medicus, JournalSeek, Journal Citation Reports/Science Edition, Directory of Open Access Journals (DOAJ), African Journal Online, Bioline International, Open-J-Gate and Pharmacy Abstracts

\section{INTRODUCTION}

Traumatic brain injury (TBI) is a major cause of death and persistent disability [1]. In addition, it is reported that over $5 \%$ of patients with moderate injury, and $16 \%$ of patients with severe injury would develop posttraumatic epilepsy [2,3]. The mechanisms underlying secondary brain damage following TBI are complex and involve two main stages: traumatic cerebral edema and delayed neuronal damage [1-3]. Delayed neuronal damage leads to irreversible necrosis or apoptosis of neurons, which could affect the long-term prognosis and quality of life in patients $[1,2,4,5]$. It is known that NF-kappa B (NF-KB) can result in neuronal damage by apoptosis. In addition, the c-myc gene could also promote apoptosis of neurons. Fatty acid synthase (Fas) is a transmembrane protein belonging to the tumor necrosis factor (TNF) superfamily. Interaction between Fas and its ligand (Fasl) is 
one of the main pathways for inducing apoptosis [6-9].

Erythropoietin (EPO), which is mainly produced by the kidneys and liver, can affect hematopoietic stem cells present in the bone marrow. Recent research has indicated that EPO can be secreted by astrocytes (paracrine secretion) in the central nervous system (CNS) [10]. Furthermore, the secreted EPO could bind to the EPO receptors present on neuronal membranes nearby. Furthermore, EPO could also protect the nerves from secondary brain damage after TBI by relieving cerebrum edema [11], facilitating neuronal regeneration [12], lowering toxicity of excitatory amino acid neurotransmitters [13], and playing anti-oxidative effect [14]. Our present study used the r-HuEPO to treat traumatic brain injury in rats, and explore the effects of $r$-HuEPO on the expressions of NF-kB, c-myc and Fas/Fasl in brain tissue.

\section{EXPERIMENTAL}

\section{Materials}

The r-HuEPO was purchased from the Shenyang Shansheng pharmaceutical Co., LTD (Shenyang, China); the primary antibodies of NF-kB and Fas/Fasl were purchased from the Santa Cruz Biotech. (Shanghai, China); the primary antibodies of c-myc were purchased by ZSGB Biotech (Shanghai, China); the secondary antibodies reagents of Envision were purchased from the Fuzhou Maixin Co., Ltd (Fuzhou, China). All the other chemical reagents used in our study were of analytical grade.

\section{TBI rat preparation and grouping}

A total of 48 healthy adult male SD rats (weighing between 280 and 320 g) were randomly divided into 4 groups: normal saline treated groups (control) and rhEPO treated groups at the doses of $1000 \mathrm{U} / \mathrm{kg}, 3000 \mathrm{U} / \mathrm{kg}$ rhEPO and $5000 \mathrm{U} / \mathrm{kg}$. TBI rats were prepared by using the Modified Feeney's free-falling model [15]. The trauma preparation device consisted of steel weights falling freely by gravity from a designated height through a Plexiglas tube. The rats were anesthetized with $0.35 \%$ pentobarbital sodium solution $(30 \mathrm{mg} / \mathrm{kg}$, intraperitoneal injection (ip). After exposing the left parietal bone by a midline incision, a port with $3 \mathrm{~mm}$ diameter was formed by dentistry auger. Thereafter, a 20 $\mathrm{g}$ weight was dropped on the exposed dura from $40 \mathrm{~cm}$ height. Drugs were administered immediately (ip) after trauma, and the drug was injected every $24 \mathrm{~h}$ until 7 th day after trauma. All animal experiments were strictly accorded to the international ethical guidelines and the National Institutes of Health Guide concerning the Care and Use of Laboratory Animals, and the experiments were carried out followed the approval of the Animal Experimentation Ethics Committee of our Hospital (Ethical approval No.201312-A87).

\section{Sample collection and evaluation}

Brain tissues were collected at 7th day after trauma and fixed in formaldehyde. The damaged area of brain was imbedded with paraffin, and then, sliced. The NF-kB-, c-myc- and Fas/Faslpositive cells, as well as apoptotic cells in brain tissues were detected by immuno-histochemistry assay. Cells with yellowish-brown grains in cell nucleus or endochylema were considered as positive expressions.

\section{Statistical analysis}

All data are expressed as mean \pm standard deviation (SD) and analyzed by SPSS 10.0 statistical analysis software using analysis of variance (ANOVA). Differences were considered significant at $p<0.05$.

\section{RESULTS}

As shown in Table 1 and Plate 1, the positive expression levels of NF-KB and Fas/Fasl in rHuEPO treated TBI rats at the doses of 3000 and $5000 \mathrm{U} / \mathrm{kg}$ were significantly decreased ( $p<$ $0.05)$, compared with the normal saline treatment group (control group), particularly in the 5000 $\mathrm{U} / \mathrm{kg}$ treated group $(p<0.01)$. However, no significant difference in the $c$-myc expression was observed in each r-HuEPO treatment group $(p>0.05)$. Compared with the $1000 \mathrm{U} / \mathrm{kg} \mathrm{r}$ HuEPO treated group, the positive expressions of c-myc and Fas/Fasl were significantly lower in $3000 \mathrm{U} / \mathrm{kg}$ r-HuEPO group $(p<0.05)$, and the positive expression levels of NF-KB and Fas/Fasl in $5000 \mathrm{U} / \mathrm{kg} \mathrm{r}$-HuEPO treated group were significantly lower $(p<0.05)$. Compared with the $3000 \mathrm{U} / \mathrm{kg} \mathrm{r}$-HuEPO treated group, only the positive expression levels of NF-KB and Fasl in $5000 \mathrm{U} / \mathrm{kg} \mathrm{r}$-HuEPO group were significantly lower $(p<0.05)$. The results also indicated that the number of apoptotic cells in r-HuEPO treated group $(5000 \mathrm{U} / \mathrm{kg})$ was significantly lower compared with the control group $(p<0.05$, Plate 2). 
Table 1: Expressions of NF-kB, c-myc and Fas/Fasl, and number of apoptotic cells

\begin{tabular}{lccccc}
\hline Group & NF-kB & c-myc & Fas & Fasl & $\begin{array}{c}\text { No. of apoptotic } \\
\text { cells }\end{array}$ \\
\hline Control & $48.83 \pm 7.42$ & $35.51 \pm 8.98$ & $44.80 \pm 7.30$ & $35.91 \pm 5.37$ & $62.18 \pm 7.05$ \\
1000 & $46.79 \pm 6.28$ & $40.20 \pm 5.65$ & $40.18 \pm 7.58$ & $33.11 \pm 8.46$ & $54.40 \pm 8.45^{\mathrm{a}}$ \\
3000 & $40.07 \pm 4.88^{\mathrm{a}}$ & $32.73 \pm 8.60^{\mathrm{b}}$ & $32.76 \pm 9.30^{\mathrm{ab}}$ & $28.33 \pm 5.60^{\mathrm{ab}}$ & $51.86 \pm 9.30^{\mathrm{a}}$ \\
5000 & $32.92 \pm 6.75^{\mathrm{abc}}$ & $34.97 \pm 9.63$ & $33.50 \pm 6.09^{\mathrm{ab}}$ & $22.52 \pm 3.87^{\mathrm{abc}}$ & $45.57 \pm 6.90^{\mathrm{ab}}$ \\
\hline
\end{tabular}

Data were represented as mean $\pm \mathrm{SD}(\mathrm{n}=12) ;{ }^{\mathrm{a}} \mathrm{p}<0.05$, compared with control; ${ }^{\mathrm{b}} \mathrm{p}<0.05$, compared with $1000 \mathrm{U} / \mathrm{kg} ;{ }^{c} p<0.05$, compared with $3000 \mathrm{U} / \mathrm{kg}$

Treatment group

NF-kB

c-myc

Fas

Fasl

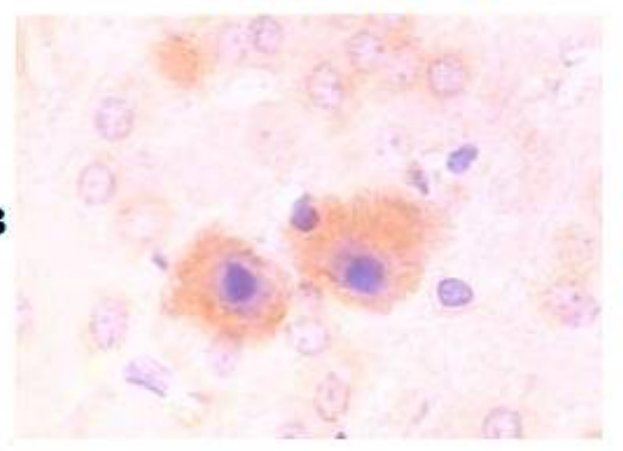

(4)

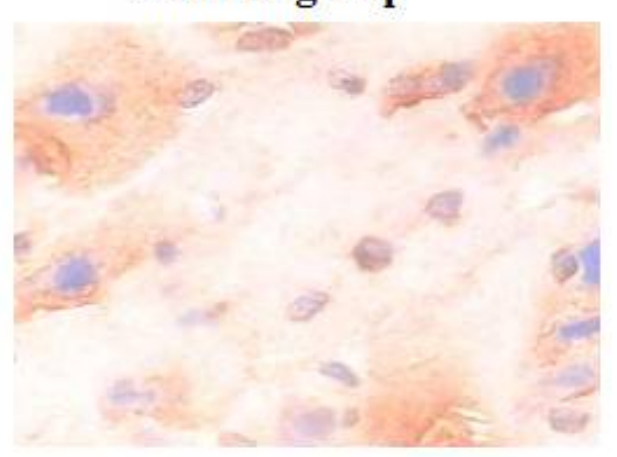

\section{Control group}
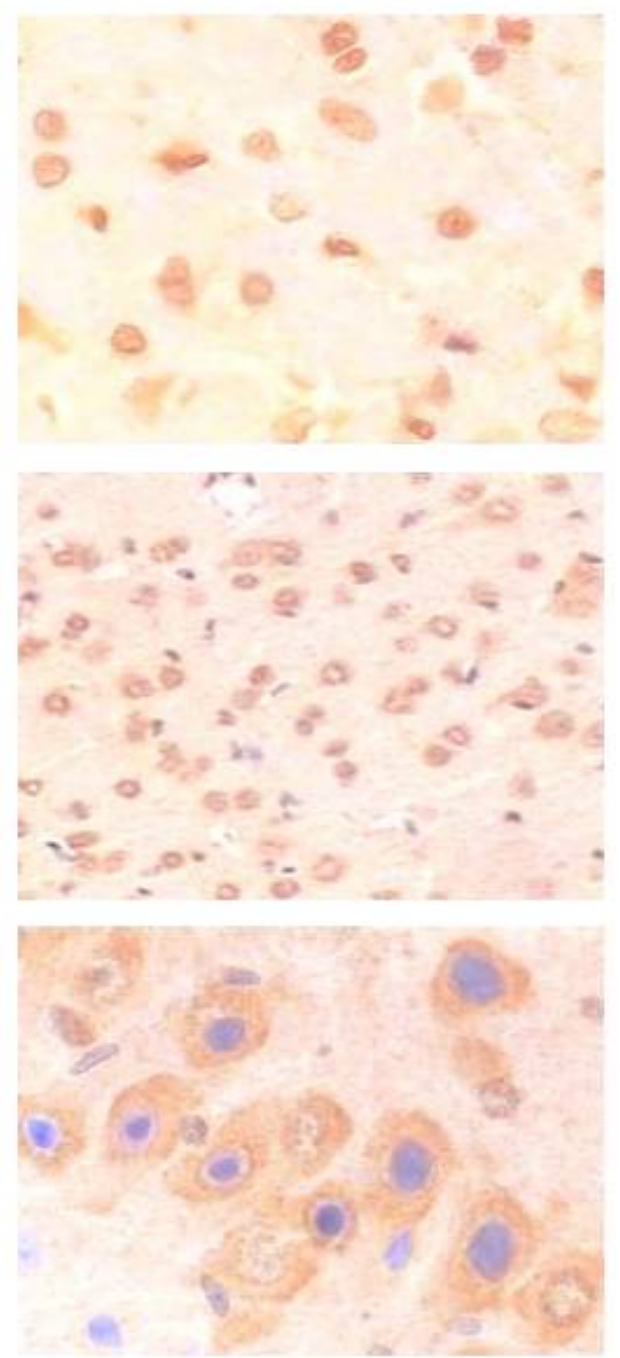

Plate 1: Expressions of NF-KB, c-myc and Fas/Fasl in brain tissues (SP staining $\times 100$ ) 


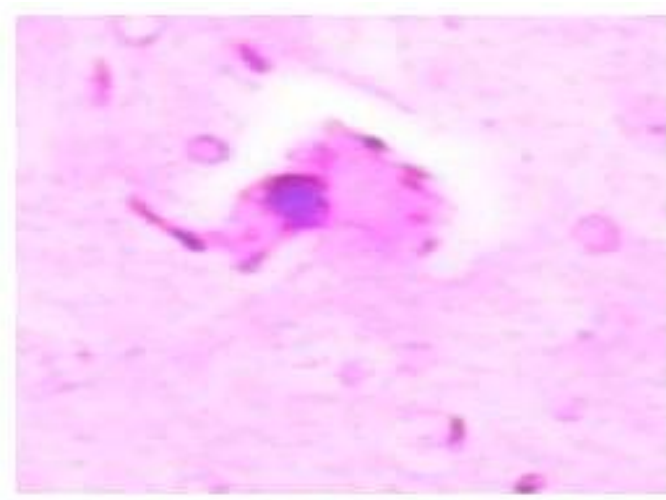

Treatment group

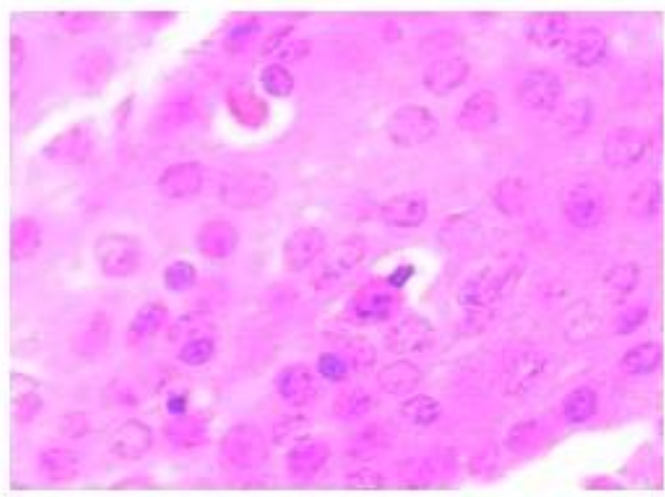

Control group

Plate 2: Apoptotic cells in brain tissues (SP staining $\times 100$ )

\section{DISCUSSION}

After traumatic brain injury, the overexpression of pro-apoptotic genes will increase the tardus injury and irreversible degeneration necrosis or apoptosis of neurons, causing more serious consequences than traumatic brain edema. In this study, after traumatic brain injury, a large number of apoptotic cells were detected in the cerebral cortex of the control rats, indicating that neuronal apoptosis plays a curial role in secondary brain damage after traumatic brain injury. Interestingly, after treating with r-HuEPO, the expressions of pro-apoptotic proteins including NF-kB, c-myc and Fas/Fasl were significantly decreased compared with control group. In particular, after administration of $r$ HuEPO at the dose of $5000 \mathrm{U} / \mathrm{kg}$, the expressions of pro-apoptotic genes were suppressed most obviously. However, no obvious difference was observed in the r-HuEPO treatment rats for the expression of c-myc gene. The findings demonstrate that $\mathrm{r}$-HuEPO has treatment effects on the expression of NF-KB, cmyc, Fas and Fasl. In addition, our results also indicate that large dose of $r$-HuEPO has a strong suppressive effect on NF-kB and Fasl expression.

Clinically reports revealed that prolonged usage of large doses of EPO may result in lots of side effects, such as increased blood volume, increased blood viscosity, and high blood pressure due to the proliferation of red blood cells $[15,16]$. Recently, Erbayraktar et al have developed a novel kind of EPO that does not contain the sialic acid group [17]. Interestingly, Erbayraktar found that this EPO did not promote the proliferation of red blood cells, and that it had a short half-life in the blood plasma, thereby avoiding the above-mentioned side effects. It also performed a better nerve-protective effect in the nervous system through the blood-brain barrier. Combined with the results of our study, it can be assumed that EPO might be used in clinical treatments to reduce neuronal damages after traumatic brain injuries.

\section{CONCLUSION}

The findings of this investigation suggest that EPO effectively suppresses the pro-apoptotic proteins, NF-KB and Fas/Fasl, after traumatic brain injuries in rats, and hence reduce neuronal damage. These findings provide some experimental evidence for the clinical use of EPO in treating severe traumatic brain injuries, especially in improving long-term prognosis and improving patients' quality of life.

\section{REFERENCES}

1. Gao WW, Zhao ZL, Yu GJ, Zhou ZW, Zhou Y, Hu TT, Jiang RC, Zhang JN. VEGI attenuates the inflammatory injury and disruption of blood-brain barrier partly by suppressing the TLR4/NF-KB signaling pathway in experimental traumatic brain injury. Brain Res 2015; 1622: 230-239.

2. Bolkvadze T, Rantala J, Puhakka N, Andrade P, Pitkänen A. Epileptogenesis after traumatic brain injury in Plaudeficient mice. Epilepsy Behav 2015; 51: 19-27.

3. Gaither JB, Galson S, Curry M, Mhayamaguru $M$, Williams C, Keim SM, Bobrow BJ, Spaite DW. Environmental hyperthermia in prehospital patients with major traumatic brain injury. J Emerg Med 2015; 49: 375-381.

4. Angeloni C, Prata C, Dalla Sega FV, Piperno R, Hrelia S. Traumatic brain injury and NADPH oxidase: a deep relationship. Oxid Med Cell Longev 2015; 2015: 370312.

5. Li Y, Lein PJ, Ford GD, Liu C, Stovall KC, White TE, Bruun DA, Tewolde T, Gates AS, Distel TJ, SurlesZeigler MC, Ford $B D$. Neuregulin-1 inhibits neuroinflammatory responses in a rat model of organophosphate-nerve agent-induced delayed neuronal injury. J Neuroinflammation 2015; 12: 64. 
6. Chen G, Shi JX, Hang CH, Xie W, Liu J, Liu X. Inhibitory effect on cerebral inflammatory agents that accompany traumatic brain injury in a rat model: a potential neuroprotective mechanism of recombinant human erythropoietin (rhEPO). Neurosci Lett 2007; 425: 177182.

7. Hu J, Luo CX, Chu WH. 20-Hydroxyecdysone protects against oxidative stress-induced neuronal injury by scavenging free radicals and modulating NF-KB and JNK pathways. PLoS One 2012; 7: e50764.

8. Lu Y, Zhang J, Ma B, Li K, Li X, Bai H, Yang Q, Zhu X, Ben J, Chen $Q$. Glycine attenuates cerebral ischemia/reperfusion injury by inhibiting neuronal apoptosis in mice. Neurochem Int 2012; 61: 649-658.

9. Yu WR, Liu T, Kiehl TR, Fehlings MG. Human neuropathological and animal model evidence supporting a role for Fas-mediated apoptosis and inflammation in cervical spondylotic myelopathy. Brain 2011; 134: 1277-1292.

10. Niu FN, Zhang X, Hu XM. Targeted mutation of Fas ligand gene attenuates brain inflammation in experimental stroke. Brain Behav Immun 2012; 26: 6171.

11. Xu F, Yu ZY, Ding L, Zheng SY. Experimental studies of erythropoietin protection following traumatic brain injury in rats. Exp Ther Med 2012; 4: 977-982.
12. Cho YK, Kim G, Park S, Sim JH, Won YJ, Hwang $\mathrm{CH}$, Yoo JY, Hong HN. Erythropoietin promotes oligodendrogenesis and myelin repair following lysolecithin-induced injury in spinal cord slice culture. Biochem Biophys Res Commun 2012; 417: 753-759.

13. Keller M, Yang J, Griesmaier E, Gorna A, Sarkozy G, Urbanek $M$, Gressens $P$, Simbruner $G$. Erythropoietin is neuroprotective against NMDA-receptor-mediated excitotoxic brain injury in newborn mice. Neurobiol Dis 2006; 24: 357-366.

14. Ponce LL, Navarro JC, Ahmed O. Erythropoietin neuroprotection with traumatic brain injury. Pathophysiol 2013; 20: 31-38.

15. Chatagner A, Hüppi PS, Ha-Vinh Leuchter $R$. Erythropoietin and neuroprotection. Arch Pediatr 2010; 17: S78-84.

16. Feeney DM, Boyeson MG, Linn RT. Responses to cortical injury: I. Methodology and local effects of contusions in the rat. Brain Res 1981; 211: 67-77.

17. Erbayraktar S, Grasso G, Sfacteria $A$. Asialoerythropoietin is anonerythropoietic cytokine with broad neuro-protcetive activity in vivo. Proc Natl Acad Sci USA 2003; 100: 6741-6746. 